Correspondence

Alan A. DiSpirito

aland@iastate.edu

Received 29 April 2005 Revised 15 July 2005 Accepted 20 July 2005

\section{Effect of methanobactin on the activity and electron paramagnetic resonance spectra of the membrane-associated methane monooxygenase in Methylococcus capsulatus Bath}

\author{
Dong W. Choi, ${ }^{1}$ William E. Antholine, ${ }^{2}$ Young S. Do, ${ }^{1}$ Jeremy D. Semrau, ${ }^{3}$ \\ Clint J. Kisting, ${ }^{1}$ Ryan C. Kunz, ${ }^{1} \dagger$ Damon Campbell, ${ }^{4}$ Vinay Rao, ${ }^{4}$ \\ Scott C. Hartsel $^{4}$ and Alan A. DiSpirito ${ }^{1}$ \\ ${ }^{1}$ Department of Biochemistry, Biophysics and Molecular Biology, 4164 Molecular Biology \\ Building, lowa State University, Ames, IA 50011-3211, USA \\ ${ }^{2}$ Department of Biophysics, Medical College of Wisconsin, Milwaukee, WI 53226, USA \\ ${ }^{3}$ Department of Civil and Environmental Engineering, University of Michigan, Ann Arbor, \\ MI 48109-2125, USA \\ ${ }^{4}$ Department of Chemistry, University of Wisconsin-Eau Claire, Eau Claire, WI 54702, USA
}

Improvements in the purification of methanobactin $(\mathrm{mb})$ from either Methylosinus

trichosporium $\mathrm{OB}^{\mathrm{B}}{ }^{\top}$ or Methylococcus capsulatus Bath resulted in preparations that stimulated methane-oxidation activity in both whole-cell and cell-free fractions of Methylococcus capsulatus Bath expressing the membrane-associated methane monooxygenase (pMMO). By using washed membrane factions with pMMO activities in the $290 \mathrm{nmol}$ propylene oxidized $\mathrm{min}^{-1}(\mathrm{mg} \text { protein })^{-1}$ range, activities approaching $400 \mathrm{nmol}$ propylene oxidized $\mathrm{min}^{-1}$ (mg protein $)^{-1}$ were commonly observed following addition of copper-containing $\mathrm{mb}(\mathrm{Cu}-\mathrm{mb})$, which represented $50-75 \%$ of the total whole-cell activity. The stimulation of methane-oxidation activity by $\mathrm{Cu}-\mathrm{mb}$ was similar to or greater than that observed with equimolar concentrations of $\mathrm{Cu}(\mathrm{II})$, without the inhibitory effects observed with high copper concentrations. Stimulation of $\mathrm{pMMO}$ activity was not observed with copper-free $\mathrm{mb}$, nor was it observed when the copper-to-mb ratio was $<0.5 \mathrm{Cu}$ atoms per mb. The electron paramagnetic resonance (EPR) spectra of mb differed depending on the copper-to-mb ratio. At copper-to-mb ratios of $<0 \cdot 4 \mathrm{Cu}(\mathrm{II})$ per $\mathrm{mb}, \mathrm{Cu}(\mathrm{II})$ addition to $\mathrm{mb}$ showed an initial coordination by both sulfur and nitrogen, followed by reduction to $\mathrm{Cu}(\mathrm{I})$ in $<2 \mathrm{~min}$. $\mathrm{At} \mathrm{Cu}(\mathrm{II})$-to-mb ratios between 0.4 and $0.9 \mathrm{Cu}(\mathrm{II})$ per $\mathrm{mb}$, the intensity of the $\mathrm{Cu}(\mathrm{II})$ signal in EPR spectra was more representative of the $\mathrm{Cu}(\mathrm{II})$ added and indicated more nitrogen coordination. The EPR spectral properties of $\mathrm{mb}$ and $\mathrm{pMMO}$ were also examined in the washed membrane fraction following the addition of $\mathrm{Cu}(\mathrm{II}), \mathrm{mb}$ and $\mathrm{Cu}-\mathrm{mb}$ in the presence or absence of reductants (NADH or duroquinol) and substrates $\left(\mathrm{CH}_{4}\right.$ and/or $\left.\mathrm{O}_{2}\right)$. The results indicated that $\mathrm{Cu}-\mathrm{mb}$ increased electron flow to the pMMO, increased the free radical formed following the addition of $\mathrm{O}_{2}$ and decreased the residual free radical following the addition of $\mathrm{O}_{2}$ plus $\mathrm{CH}_{4}$. The increase in pMMO activity and EPR spectral changes to the pMMO following $\mathrm{Cu}-\mathrm{mb}$ addition represent the first positive evidence of interactions between the pMMO and $\mathrm{Cu}-\mathrm{mb}$.
†Present address: Department of Biochemistry, Beadle Center, University of Nebraska, Lincoln, NE 68588-0664, USA.

Abbreviations: $\mathrm{Cu}-\mathrm{mb}$, copper-containing methanobactin; EPR, electron paramagnetic resonance; mb, methanobactin; MALDI-TOF, matrixassisted laser desorption ionization-time-of-flight; $\mathrm{MMO}$, methane monooxygenase; pMMO, membrane-associated methane monooxygenase; sMMO, soluble methane monooxygenase.

Supplementary material is available with the online version of this paper.

\section{INTRODUCTION}

Methanobactin (mb), previously called copper-binding compound or copper-binding peptide, was initially identified in the methanotroph Methylococcus capsulatus Bath in association with the membrane-associated or particulate methane monooxygenase (pMMO) (Zahn \& DiSpirito, 1996). This copper-binding molecule was later identified in 
the extracellular fractions of both Methylococcus capsulatus Bath and Methylosinus trichosporium $\mathrm{OB}^{\mathrm{b}}{ }^{\mathrm{T}}$ (D. W. Choi, Y. S. Young, J. D. Semrau, W. E. Antholine, C. J. Kisting, S. C. Hartsel \& A. A. DiSpirito, unpublished results; DiSpirito et al., 1998; Fitch et al., 1993; Kim et al., 2004, 2005; Téllez et al., 1998). Copper-containing $\mathrm{mb}(\mathrm{Cu}-\mathrm{mb})$ was originally proposed as a cofactor of the pMMO, based on the irreversible loss of pMMO activity following separation (Choi et al., 2003; Zahn \& DiSpirito, 1996). In this model, the core enzyme was composed of three polypeptides with approximate molecular masses of 45000 ( $\alpha$ subunit), 25000 ( $\beta$ subunit) and 20000 ( $\gamma$ subunit) Da in a 1:1:1 ratio. The $\alpha \beta \gamma$ subunits of the $\mathrm{pMMO}$ were believed to contain two type II $\mathrm{Cu}(\mathrm{II})$ and two electron paramagnetic resonance (EPR)silent $\mathrm{Fe}$ atoms. Active preparations also contained 8-13 $\mathrm{Cu}-\mathrm{mb}$. The crystal structure of the core enzyme has recently been determined (Lieberman \& Rosenzweig, 2005; Sommerhalter et al., 2005). The crystal structure showed that the enzyme is a trimer, $(\alpha \beta \gamma)_{3}$. Each $\alpha \beta \gamma$ monomer contained one type II $\mathrm{Cu}(\mathrm{II})$ atom and two copper atoms that appear to be spin-coupled, similar to the $\mathrm{Cu}_{\mathrm{A}}$ in cytochrome $c$ oxidase, or a modified type III site associated with the $\beta$ subunit (Boas, 1984; Lieberman \& Rosenzweig, 2005). The enzyme was also reported to contain one $\mathrm{Zn}(\mathrm{II})$ atom coordinated between the $\alpha$ and $\beta$ subunits (Lieberman $\&$ Rosenzweig, 2005). The source of the $\mathrm{Zn}$ (II) was proposed to be the crystallization buffer, as no $\mathrm{Zn}$ (II) was associated with the enzyme preparations before crystallization. Further, the results of these studies suggested that the $\mathrm{Zn}$ (II) may have replaced another metal, such as $\mathrm{Cu}$ or Fe. The pMMO preparation used in the crystallization study was inactive, so the absence of $\mathrm{Cu}-\mathrm{mb}$ in the crystal structure was not surprising, considering that $\mathrm{Cu}-\mathrm{mb}$ is easily dissociated from the $\alpha \beta \gamma$ polypeptides of the pMMO (Choi et al., 2003; Zahn \& DiSpirito, 1996).

Previous studies from this laboratory have shown that highactivity pMMO preparations require co-purification of $\mathrm{Cu}-\mathrm{mb}$ with the three pMMO polypeptides (Choi et al., 2003). Additional evidence for a potential involvement of $\mathrm{Cu}-\mathrm{mb}$ in methane oxidation comes from the culture conditions used to stabilize cell-free pMMO activity, which result in an increased concentration of membraneassociated Cu-mb (Choi et al., 2003; Zahn \& DiSpirito, 1996). Studies on the role of $\mathrm{Cu}-\mathrm{mb}$ in methane oxidation by the pMMO have been limited, as the only direct correlation between these two proteins was the irreversible loss of methane-oxidation activity following dissociation. $\mathrm{Cu}-$ $\mathrm{mb}$ has been shown to have superoxide dismutase activity, which may account for its stabilizing effects on cell-free pMMO activity (Choi et al., 2003). Recent improvements in the stabilization of the pMMO in cell-free fractions (Basu et al., 2003; Choi et al., 2003; D. W. Choi, Y. S. Young, J. D. Semrau, W. E. Antholine, C. J. Kisting, S. C. Hartsel \& A. A. DiSpirito, unpublished results), as well as in the isolation of $\mathrm{mb}$ (this report) and $\mathrm{Cu}-\mathrm{mb}$ (Kim et al., 2005), however, have caused us to reconsider the potential role of $\mathrm{mb}$ and $\mathrm{Cu}-\mathrm{mb}$ in methane oxidation. In this study, we show that
$\mathrm{Cu}-\mathrm{mb}$ stimulates pMMO activity, and the results suggest that the stimulation is due to an increased rate of electron flow to the type II $\mathrm{Cu}(\mathrm{II})$ centre(s) of the pMMO.

\section{METHODS}

Organisms, culture conditions and isolation of membrane fractions. Methylosinus trichosporium $\mathrm{OB}^{\mathrm{T}} \mathrm{b}^{\mathrm{T}}$ and Methylococcus capsulatus Bath were cultured for $\mathrm{mb}$ isolation in nitrate minimal salts (NMS) medium containing $0,0 \cdot 2$ or $1 \mu \mathrm{M}$ added $\mathrm{CuSO}_{4}$, as described previously (Choi et al., 2003). The initial copper concentration in NMS medium with no added $\mathrm{CuSO}_{4}$ was $0 \cdot 29 \pm 0 \cdot 04 \mu \mathrm{M}$. The cultures were grown in batch mode to an $\mathrm{OD}_{600}$ between $0 \cdot 7$ and 1.2 prior to harvesting for $\mathrm{mb}$. When the $\mathrm{OD}_{600}$ reached the desired level, $80 \%$ of the fermenter was harvested and replaced with fresh NMS medium. Methylococcus capsulatus Bath was also cultured in NMS medium that contained a final $\mathrm{CuSO}_{4}$ concentration of either 60 or $80 \mu \mathrm{M}$, as described previously (Choi et al., 2003). Washed membranes from Methylococcus capsulatus Bath were isolated under anaerobic conditions as described by Choi et al. (2003).

Isolation of $\mathbf{m b}$. $\mathrm{Cu}-\mathrm{mb}$ and $\mathrm{mb}$ were prepared from the spent medium of Methylosinus trichosporium $\mathrm{OB}^{3} \mathrm{~b}^{\mathrm{T}}$ or Methylococcus capsulatus Bath. For each harvest, the spent medium was centrifuged twice at $9000 \mathrm{~g}$ for $20 \mathrm{~min}$ to remove residual cells. At this stage, the spent medium was either loaded onto a $7 \times 20 \mathrm{~cm}$ Dianion HP-20 column (Supelco) or stabilized by the addition of copper as described by Kim et al. (2004), except that the final concentration of added copper was reduced from 10 to $1 \mathrm{mM}$. The Dianion HP-20 column was washed with two column volumes of $\mathrm{H}_{2} \mathrm{O}$, eluted with $60 \%$ methanol: $40 \%$ water $(\mathrm{v} / \mathrm{v})$ and lyophilized. At this stage of purification, mb represented $>97 \%$ of the material absorbing at 214 or $280 \mathrm{~nm}$ and no other chromophores with absorption maxima above $280 \mathrm{~nm}$ were present. Purity of mb samples was checked at this stage by HPLC, matrix-assisted laser desorption ionizationtime-of-flight (MALDI-TOF) mass spectrometry and UV-visible absorption spectra. Unless indicated, the freeze-dried samples following chromatography on Dianion HP-20 columns were the source of $\mathrm{mb}$ or $\mathrm{Cu}-\mathrm{mb}$ used in this study. Selected samples were purified further by reverse-phase HPLC on a Beckman Gold HPLC system by using a SupelcoSil LC-18 $(25 \mathrm{~cm} \times 4.6 \mathrm{~mm}, 5 \mu \mathrm{m})$ column at a flow rate of $1.0 \mathrm{ml} \mathrm{min}{ }^{-1}$, with $10 \mathrm{mM}$ sodium phosphate buffer, pH 6.6 (solvent A) and $80 \%$ acetonitrile/ $\mathrm{H}_{2} \mathrm{O}$ (solvent B) as the mobile phase. A linear gradient consisting of an initial solvent $\mathrm{B}$ concentration of $5 \%$ following injection to $35 \%$ solvent $\mathrm{B}$ at $50 \mathrm{~min}$ and $100 \%$ at $55 \mathrm{~min}$ was used in this purification step.

Sample purity and metal content of final samples were based on the UV-visible absorption spectra, on metal analysis and on molecular masses as determined by MALDI-TOF MS, of the fractions before and after separation by reverse-phase HPLC.

Molecular-mass determinations. Solution molecular mass of $\mathrm{mb}$ samples was determined on a Superdex Peptide HR 10/30 column (Pharmacia/LKB) equilibrated with MilliQ water (Millipore), $\mathrm{pH} \mathrm{6 \cdot 8.}$ The column was calibrated by using blue dextran, orange G, bradykinin (1240 Da), rennin substrate (1759 Da), insulin (5734 Da) and horse-heart cytochrome $c(12500 \mathrm{Da})$.

MALDI-TOF mass spectra were obtained on a Voyager-DE PRO Biospectrometry Workstation 6075 (PerSeptive Biosystems, Inc.). Analyses were performed in the reflector-positive mode with timedelayed extraction (200 ns). Acquisition-mass range was typically between 500 and $5000 \mathrm{Da}$, with laser intensities between 1900 and 2100 intensity units. The matrix solution used was $p$-nitroaniline (Fluka Chemika) (35 mM in a 1:1 mixture of water: ethanol at $\mathrm{pH} 6 \cdot 5)$. Typically, $1 \mu \mathrm{l}$ of an mb solution $\left(5 \mathrm{mg} \mathrm{ml}^{-1}\right)$ was diluted $1: 10$ with 
$p$-nitroaniline matrix. A $2 \mu$ aliquot of the analyte/matrix solution was spotted onto a stainless-steel sample plate and allowed to dry before analysis.

\begin{abstract}
Enzyme activity, isolation of cell fraction and protein determinations. Methane monooxygenase (MMO) activity was determined by the epoxidation of propylene, as described previously (Choi et al., 2003), and measured either in the liquid phase on an SRI 8610C GC system (SRI Instruments) equipped with a flameionization detector and an $8^{\prime} \times 0 \cdot 085^{\prime \prime}$ HaySep D column, or in the gas phase on a Varian 3900 (Varian Corporation) equipped with a flame-ionization detector and a $30 \mathrm{~m} \times 0.53 \mathrm{~mm}$ Supel-Q plot column. Isolation of the cell-free fraction, copper determinations and protein determinations were carried out as described previously (Choi et al., 2003). In addition to propylene-oxidation activity in the soluble fraction, soluble MMO (sMMO) activity was monitored by the formation of naphthol from naphthalene as described by Brusseau et al. (1990).
\end{abstract}

The effects of mb on pMMO activity were examined in the washed membrane fraction from Methylococcus capsulatus Bath by using mb from Methylosinus trichosporium $\mathrm{OB} 3 \mathrm{~b}^{\mathrm{T}}$. Washed membrane fractions from Methylococcus capsulatus Bath were used, as procedures for the isolation of membrane fractions with high pMMO activity have only been developed in this species (Basu et al., 2003; Choi et al., 2003; Yu et al., 2003). $\mathrm{mb}$ from Methylosinus trichosporium $\mathrm{OB}^{\mathrm{T}} \mathrm{b}^{\mathrm{T}}$ was used in these studies for a variety of reasons. First, the EPR spectra of $\mathrm{Cu}-\mathrm{mb}$ from both methanotrophs were identical (W. E. Antholine, D. W. Choi, Y. S. Young \& A. A. DiSpirito, unpublished results). Second, stimulation of pMMO activity by $\mathrm{Cu}-\mathrm{mb}$ was $10-20 \%$ higher using $\mathrm{Cu}-\mathrm{mb}$ from Methylosinus trichosporium $\mathrm{OB}^{\mathrm{b}} \mathrm{b}^{\mathrm{T}}$ than that observed with equimolar concentrations of $\mathrm{Cu}-\mathrm{mb}$ from Methylococcus capsulatus Bath (results not shown). Third, the yields of $\mathrm{mb}$ from the spent medium of Methylosinus trichosporium $\mathrm{OB}^{\mathrm{T}} \mathrm{b}^{\mathrm{T}}$ were generally severalfold higher than observed with Methylococcus capsulatus Bath (Choi et al., 2003; DiSpirito et al., 1998; Kim et al., 2005; Zahn \& DiSpirito, 1996). Fourth, the mb from Methylosinus trichosporium $\mathrm{OB}^{\mathrm{T}} \mathrm{b}^{\mathrm{T}}$ is the best-characterized mb, structurally (Kim et al., 2004, 2005), spectrally (D. W. Choi, Y. S. Young, J. D. Semrau, W. E. Antholine, C. J. Kisting, S. C. Hartsel \& A. A. DiSpirito, unpublished results; DiSpirito et al., 1998; Kim et al., 2005) and thermodynamically (D. W. Choi, Y. S. Young, J. D. Semrau, W. E. Antholine, C. J. Kisting, S. C. Hartsel \& A. A. DiSpirito, unpublished results). Lastly, the $\mathrm{Cu}-\mathrm{mb}$ from Methylosinus trichosporium $\mathrm{OB} 3 \mathrm{~b}^{\mathrm{T}}$ is more soluble than $\mathrm{Cu}-\mathrm{mb}$ samples from Methylococcus capsulatus Bath, which tend to precipitate in solutions at concentrations above $10 \mu \mathrm{M}$.

$\mathrm{Cu}-\mathrm{mb}$ and substrate effects on the EPR spectra of washed membranes. Membrane samples isolated under anaerobic conditions from Methylococcus capsulatus Bath were prepared for EPR studies in $6 \mathrm{ml}$ amber serum vials in an anaerobic chamber (Coy Laboratory), using $5 \%$ hydrogen with $95 \%$ argon. In samples containing reductants (either $\mathrm{NADH}$ or duroquinol), $2 \cdot 12 \mathrm{nmol}$ reductant was added (mg membrane protein $)^{-1}$. The concentration of reductant added was based on an estimated pMMO content of $20 \%$ in the washed membrane samples. For samples containing added $\mathrm{Cu}$ (II) or $\mathrm{Cu}-\mathrm{mb}$, the optimal molar ratio of $\mathrm{Cu}$ (II) or $\mathrm{Cu}-\mathrm{mb}$ to pMMO was chosen based on the concentration yielding the highest propylene-oxidation activity. The samples were mixed and the hypovials were sealed with Teflon-coated silicon septa. Substrates $(2 \mathrm{ml}$ $\mathrm{O}_{2}, 2 \mathrm{ml} \mathrm{CH}$ or $2 \mathrm{ml}$ of each) were added with gas-tight syringes and the samples were incubated for $5 \mathrm{~min}$ at room temperature with shaking. After incubation, samples were transferred to EPR tubes, sealed and taken out of the anaerobic chamber. Samples in EPR tubes were then frozen in liquid nitrogen and stored on dry ice.

UV-visible absorption spectroscopy. UV-visible absorption spectroscopy was performed as described previously (Choi et al.,
2003). Kinetic photodiode array spectral series were taken by using a microvolume stopped-flow reaction analyser (Applied Photophysics and SX.18MV). Spectral series were measured at $2 \cdot 0{ }^{\circ} \mathrm{C}$ from 275 to $500 \mathrm{~nm}$ by using a diode array detector with an integration time of $2.56 \mathrm{~ms}$. The mixing chamber had a $1.0 \mathrm{~cm}$ path length and the monochrometer slit width was fixed at $1.0 \mathrm{~mm}$ entry and $1.0 \mathrm{~mm}$ exit. All samples were protected from ambient light to prevent possible photo-oxidation. Pro-K SVD and global analysis software from Applied Photophysics was used for data analysis (Henry \& Hofrichter, 1992).

EPR spectrospcopy. Q-, S- and X-band EPR spectra were obtained as described by Yuan et al. (1999).

\section{RESULTS}

\section{Isolation of $\mathbf{m b}$ in the absence of copper}

The isolation of $\mathrm{Cu}-\mathrm{mb}$ has recently been reported by $\mathrm{Kim}$ et al. (2005). This purification procedure solved a number of problems associated with earlier purification procedures, such as samples of varying purity and breakdown products (DiSpirito et al., 1998; Kim et al., 2005; Zahn \& DiSpirito, 1996). In addition, in contrast to earlier studies, the $\mathrm{Cu}-\mathrm{mb}$ isolated by the procedures described in Methods or by Kim et al. (2005) stimulated pMMO activity in whole-cell and washed membrane fractions (see below). However, the mb samples isolated by the procedure of Kim et al. $(2004,2005)$ are copper-saturated (i.e. $1 \cdot 2 \pm 0 \cdot 16 \mathrm{Cu}$ per $\mathrm{mb}$ ) and dialysis against $\mathrm{Na}_{2}$ EDTA only removed approximately $90 \%$ of the $\mathrm{Cu}$ associated with $\mathrm{mb}$ (results not shown). This dialysis treatment also altered the thermodynamic and spectral properties of the sample (D. W. Choi, Y. S. Young, J. D. Semrau, W. E. Antholine, C. J. Kisting, S. C. Hartsel \& A. A. DiSpirito, unpublished results). The purification procedure was simplified to obtain low-copper-containing mb samples and to avoid the breakdown products observed in a previous purification procedures. A one-column procedure was used to purify $\mathrm{mb}$ from the spent medium (described in Methods). mb samples purified by this procedure represented $>97 \%$ of the material absorbing at 214 or $280 \mathrm{~nm}$ and contained no other chromophores (Choi et al., 2005a, b). The purified $\mathrm{mb}$ samples from this procedure contained $0 \cdot 01-0 \cdot 02 \mathrm{Cu}$ per $\mathrm{mb}$ and were stable if the samples were freeze-dried and stored in the dark at $-20^{\circ} \mathrm{C}$. Aqueous solutions of $\mathrm{mb}$ were also stable for one freeze-thaw cycle if frozen in liquid nitrogen and stored in the dark at $-80{ }^{\circ} \mathrm{C}$. Samples were stored in the dark or in amber bottles, as exposure to light resulted in photoinactivation of the sample (data not shown).

\section{Effects of $\mathrm{Cu}-\mathrm{mb}$ on pMMO activity}

The effects of $\mathrm{Cu}(\mathrm{II}), \mathrm{mb}, \mathrm{Cu}-\mathrm{mb}$ and $\mathrm{mb}$ plus $\mathrm{Cu}(\mathrm{II})$ at different molar ratios on pMMO activity in Methylococcus capsulatus Bath are shown in Fig. 1. The cells and membrane fractions used in this component of the study were from Methylococcus capsulatus Bath cultured in medium with a final copper concentration of either $60 \mu \mathrm{M} \mathrm{CuSO}_{4}$, where the expression levels of pMMO are highest, or $80 \mu \mathrm{M}$ 

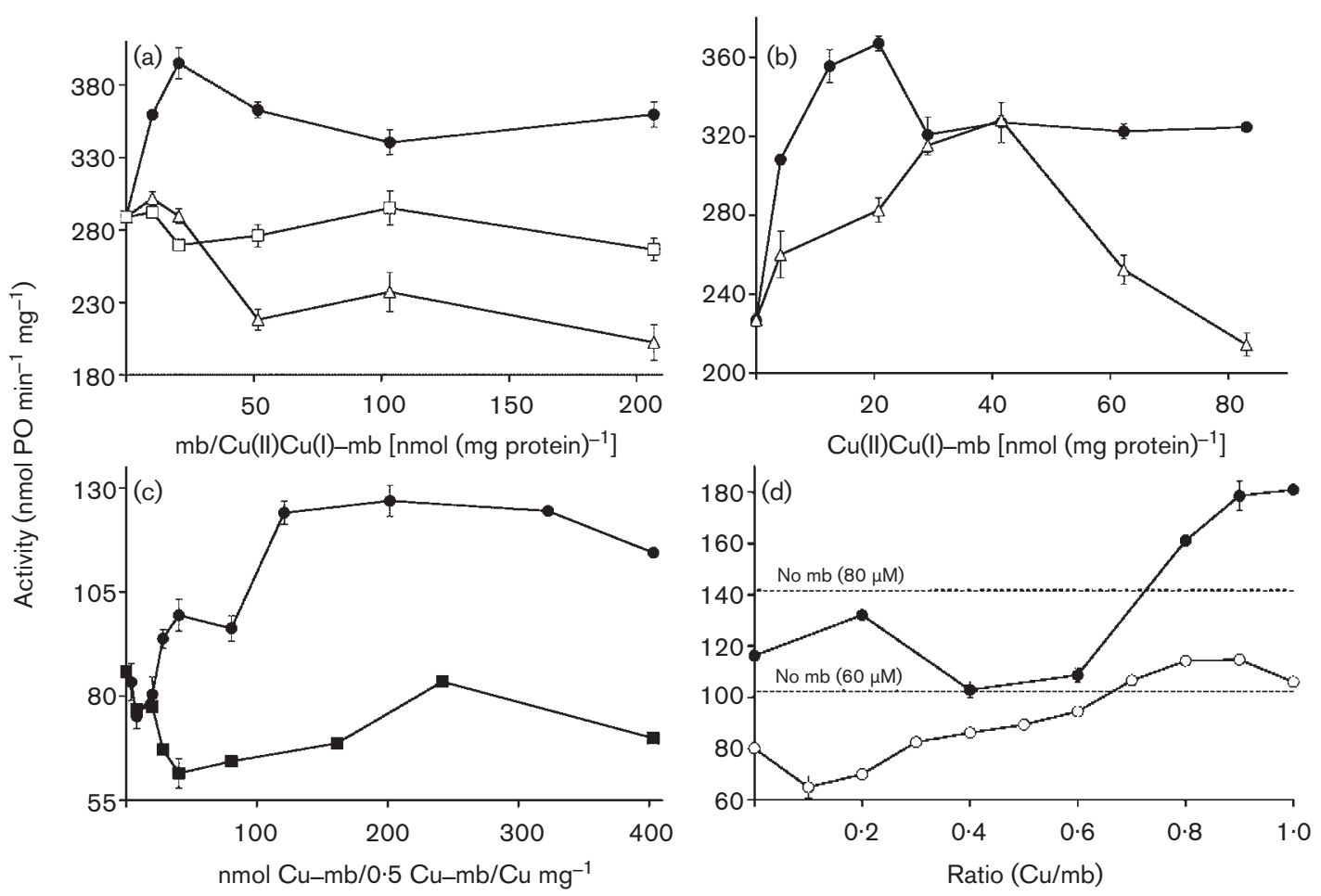

Fig. 1. Effect of $\mathrm{Cu}-\mathrm{mb}$ on the rate of propylene oxidation by Methylococcus capsulatus Bath expressing the pMMO. (a) Effect of $\mathrm{mb}(\square), \mathrm{Cu}-\mathrm{mb}(\bullet)$ and $\mathrm{CuSO}_{4}(\triangle)$ on whole-cell propylene-oxidation rates in Methylococcus capsulatus Bath. Cells were cultured in a chemostat to an $\mathrm{OD}_{600}$ of 1.2 as described previously (Choi et al., 2003) and harvested when the copper concentration added to the medium reached $80 \mu \mathrm{M}$. Protein concentration in reaction vials was $1.4 \mathrm{mg} \mathrm{ml}^{-1}$. (b) Effect of $\mathrm{CuSO}_{4}(\triangle)$ and $\mathrm{Cu}-\mathrm{mb}(\bullet)$ on propylene-oxidation rates in the washed membrane fraction of cells grown and harvested as described in (a). (c) Effect of $\mathrm{Cu}-\mathrm{mb}(\boldsymbol{O})$ and $\mathrm{Cu}(\mathrm{mb})_{2}(\boldsymbol{\nabla})$ on propylene-oxidation rates in the washed membrane fraction of cells grown and harvested as described in (a). (d) Effect of $\mathrm{Cu}(\mathrm{II})$-to-mb molar ratio on the rate of methane oxidation in the washed membrane fraction from cells cultured in $60(\bigcirc)$ or $80(\bullet) \mu \mathrm{M} \mathrm{Cu}(\mathrm{II})$. The lines labelled 'No mb (80 $\mu \mathrm{M})$ ' and 'No mb $(60 \mu \mathrm{M})$ ' illustrate the activity in the washed membrane fraction with no added mb.

$\mathrm{CuSO}_{4}$, which has been shown to saturate the cells with copper (Choi et al., 2003). The copper and mb concentrations in membrane samples of cells cultured under these conditions were approximately $250 \mathrm{nmol} \mathrm{Cu} \mathrm{(mg} \mathrm{pro-}$ tein) ${ }^{-1}$ (Choi et al., 2003) and $150 \mathrm{nmol} \mathrm{mb} \mathrm{(mg} \mathrm{pro-}$ tein $)^{-1}$. Even in cells cultured under these high-copper conditions, the addition of $\mathrm{Cu}(\mathrm{II})$ usually stimulated pMMO activity, although higher concentrations of $\mathrm{Cu}$ (II) were always inhibitory (Fig. 1a). In whole-cell samples, the stimulation of pMMO by copper was three- to fourfold higher if added as $\mathrm{Cu}-\mathrm{mb}$ (Fig. 1a). An optimal $\mathrm{Cu}-\mathrm{mb}$-tocell ratio was always observed, followed by a small decrease in pMMO activity as the $\mathrm{Cu}-\mathrm{mb}$-to-cell ratio was increased further. However, even at high $\mathrm{Cu}-\mathrm{mb}$ concentrations, the addition of $\mathrm{Cu}-\mathrm{mb}$ stimulated pMMO activity in whole-cell samples and never showed the inhibition observed with $\mathrm{Cu}(\mathrm{II})$. This stimulation was only observed with $\mathrm{Cu}-\mathrm{mb}$; $\mathrm{mb}$ itself was slightly inhibitory to whole-cell propyleneoxidation rates (Fig. 1a).

The washed membrane fractions from cells cultured above $60 \mu \mathrm{M} \mathrm{CuSO}_{4}$ showed initial propylene-oxidation activities in the range of $75-230 \mathrm{nmol} \mathrm{min}{ }^{-1}$ (mg protein $)^{-1}$, before $\mathrm{Cu}(\mathrm{II})$ or $\mathrm{Cu}-\mathrm{mb}$ additions. These propylene-oxidation rates are several-fold higher than previously reported rates (Basu et al., 2003; Chan et al., 2004; Choi et al., 2003; Lieberman et al., 2003) and are dependent on copperaddition rates during growth. Fig. 1 (b and c) represent two different membrane preparations showing high- and lowactivity membrane samples. Maintaining anaerobic conditions, eliminating light and maintaining temperatures below $4{ }^{\circ} \mathrm{C}$ during cell lysis aided in the stabilization of pMMO activity. Stimulation of pMMO activity in the washed membrane fraction by $\mathrm{Cu}(\mathrm{II})$ or by $\mathrm{Cu}-\mathrm{mb}$ was similar to that observed in whole-cell samples, except that the stimulatory and inhibitory effects were more pronounced (Fig. 1b and c). The stimulation of propylene oxidation by $\mathrm{Cu}-\mathrm{mb}$ varied from 35 to $140 \%$, depending on the membrane preparation, with activities approaching $400 \mathrm{nmol} \mathrm{min}{ }^{-1}$ (mg protein $)^{-1}$ in some membrane preparations following $\mathrm{Cu}-$ $\mathrm{mb}$ addition. In general, the stimulation of pMMO activity by $\mathrm{Cu}-\mathrm{mb}$ in washed membrane fractions increased proportionally with the copper concentrations used during growth. In addition, the percentage stimulation of pMMO 
activity by $\mathrm{Cu}-\mathrm{mb}$ increased with the initial activity of the membrane preparation.

Several recent experiments have suggested that mb may initially bind copper as a homodimer, i.e. as $\mathrm{Cu}(\mathrm{mb})_{2}$, followed by the binding of a second $\mathrm{Cu}$ (II), resulting in a final molar ratio of 1 copper atom per $\mathrm{mb}$, i.e. $\mathrm{Cu}-\mathrm{mb}$ (D. W. Choi, Y. S. Young, J. D. Semrau, W. E. Antholine, C. J. Kisting, S. C. Hartsel \& A. A. DiSpirito, unpublished results). To examine whether the pMMO in the washed membrane fraction responded differently to $\mathrm{Cu}(\mathrm{mb})_{2}$, the effect of $\mathrm{Cu}(\mathrm{mb})_{2}$ on pMMO activity was also examined (Fig. 1c). In contrast to $\mathrm{Cu}-\mathrm{mb}$, which stimulated pMMO activity, $\mathrm{Cu}(\mathrm{mb})_{2}$ was inhibitory to pMMO activity (Fig. 1c). To further examine this property, the effect of $\mathrm{mb}$ with different copper-to-mb molar ratios on pMMO activity in the washed membrane samples was examined (Fig. 1d). In general, mb was inhibitory to pMMO activity at copper-to-mb molar ratios of $<0.6$ copper atoms per mb and stimulatory at concentrations above $0 \cdot 6-0 \cdot 8$ copper atoms per mb (Fig. 1d).

\section{EPR spectra of $\mathrm{mb}$}

In an attempt to identify $\mathrm{Cu}-\mathrm{mb}$ spectrally in the washed membrane fraction of methanotrophs, the EPR spectral properties of purified $\mathrm{mb}$ were examined by X-, Q- and Sband EPR. The EPR spectrum of $\mathrm{Cu}-\mathrm{mb}$ at the conventional microwave frequency (X-band) and at a higher (Q-band) and a lower (S-band) frequency confirms the binding of cupric ion (Fig. 2). Two observations distinguish the Xband spectrum of $\mathrm{Cu}-\mathrm{mb}$. First, the lines in the low-field region $\left[g_{11}=2 \cdot 23, A_{11}=185 \mathrm{G}\left(1 \mathrm{G}=10^{-4} \mathrm{~T}\right)\right]$ were broader than usual (Boas, 1984). This indicates more strain in the axial direction than is observed from most type II cupric complexes. These lines in the $\mathrm{g}_{11}$ region were sharper at a lower microwave frequency (S-band trace in Fig. 2) and broader at higher microwave frequencies (Q-band). For Qband analysis, the $\mathrm{g}_{11}$ lines were broad and not detected (not shown). In the X-band spectrum, there were lines at high field, split by $16 \mathrm{G}$. These lines split by $16 \mathrm{G}$ were also evident in the S-band spectrum on the S-shaped signal from the $\mathrm{g}_{1}$ region. The first harmonic of the S-band trace emphasizes the sharp lines. The Q-band spectrum also has sharp lines on the high-field side, which are attributed to the $\mathrm{g}_{\perp}$ region. Superimposed on the $\mathrm{Cu}-\mathrm{mb}$ lines were five or six Mn lines and a free-radical signal that were not detected at X- or S-band. Q-band spectra contained Mn and freeradical signals that were considered background signals. The first harmonic of the Q-band spectrum emphasizes the sharp lines. They are part of the $g_{\perp}$ region from an axialsymmetric site and not from $g_{x}$ for a rhombic site with three $g$ values $\left(g_{\mathrm{z}}, g_{\mathrm{y}}, g_{\mathrm{x}}\right)$, because the $g_{\mathrm{x}}$ peak would be superimposed about the free radical in the Q-band spectrum if this was a true $g$ value. Presumably, the shoulder on the highfield side in the X-band spectrum was an overshoot line that disappears in the Q-band spectrum, as expected for an overshoot line at X-band. As there were at least 10 lines split by $16 \mathrm{G}$ that were resolved and probably more unresolved

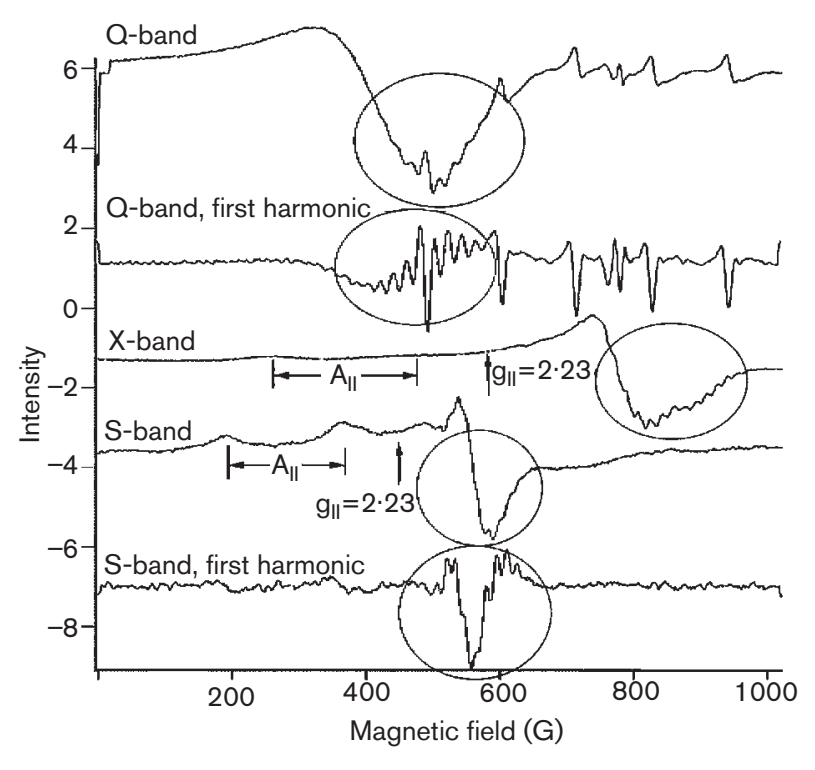

Fig. 2. Q-, S- and X-band EPR spectra of $\mathrm{Cu}-\mathrm{mb}$ at $77 \mathrm{~K}$. The regions with lines split by $16 \mathrm{G}$ are circled. $A_{\|}$and $g_{\|}$are indicated by lines and arrows. Spectrometer conditions were as follows. X-band: microwave frequency, 9.195 GHz; microwave power, $5 \mathrm{~mW}$; temperature, $77 \mathrm{~K}$; four scans averaged. Sband: microwave frequency, $3.334 \mathrm{GHz}$; microwave power, $16 \mathrm{~dB}$ (incident power, $10 \mathrm{~mW}$ ); temperature, $-140^{\circ} \mathrm{C}$; four scans averaged. Q-band: microwave frequency, $34 \cdot 786 \mathrm{GHz}$; microwave power, $26 \mathrm{~dB}$; temperature, $-140^{\circ} \mathrm{C}$; nine scans averaged. The modulation amplitude was $5 \mathrm{G}$, scan time was $4 \mathrm{~min}$ and the time constant was $0.128 \mathrm{~s}$ for all spectra.

lines in the spectra, these lines were attributed to superhyperfine lines due to nitrogen-donor atoms in addition to protons that are close to the cupric ion. It is surmised that the cupric-binding site was formed from three or four nitrogen-donor atoms, due to the number of lines resolved, the $g_{11}$ value of $2 \cdot 23$ and the $A_{11}$ value of $185 \mathrm{G}$.

Consistent with earlier studies (DiSpirito et al., 1998; Zahn \& DiSpirito, 1996) and recent X-ray photoelectron spectroscopy (Kim et al., 2004), the EPR spectra of mb showed that the copper associated with mb was predominantly $\mathrm{Cu}(\mathrm{I})$ and not EPR-detectable (Figs 3 and 4). In copper-titration experiments, the mb concentration was $4 \mathrm{mM}$ and $\mathrm{CuSO}_{4}$ additions started at $240 \mu \mathrm{M}(0.06$ molar equivalents $)$, which should have provided a strong signal if the copper remained as $\mathrm{Cu}(\mathrm{II})$. However, in the spectra following the addition of $0 \cdot 06,0 \cdot 125,0 \cdot 25$ and $0 \cdot 3$ molar equivalents of $\mathrm{Cu}(\mathrm{II})$, the signal remained lower than expected and the residual $\mathrm{Cu}(\mathrm{II})$ has $g_{\|}$about $2 \cdot 20$ and $A_{\| \mid}$about $180 \mathrm{G}$, indicative of thiol coordination, but there appears to be more than a single cupric site. The spectra in these samples were complex and fell between predictable values for the projected $2 \mathrm{~N} 2 \mathrm{~S}$ and $3 \mathrm{~N} 1 \mathrm{~S}$ coordination, which may be due to the oxidation of one of the sulfurs associated with the imidazole group. At $\mathrm{Cu}$ (II) additions above $0 \cdot 4$ molar equivalents, the intensity of the spectra was more in keeping with the concentration of 


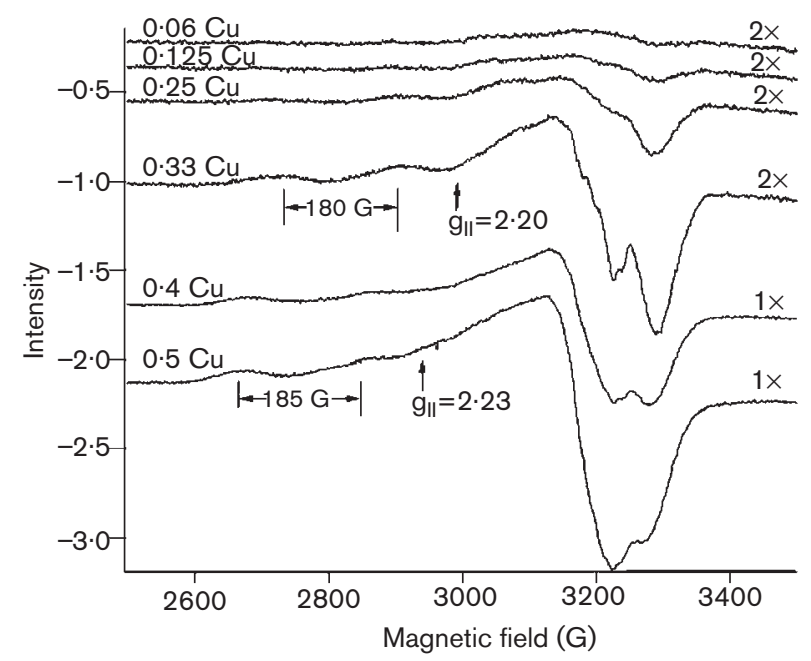

Fig. 3. X-band EPR spectra at $77 \mathrm{~K}$ of $\mathrm{mb}(4 \mathrm{mM})$ following the addition of $0.06,0.125,0.25,0.33,0.4$ and 0.5 molar equivalents of $\mathrm{CuSO}_{4} . \mathrm{A}_{\|}$and $\mathrm{g}_{\|}$are indicated by lines and arrows. Experimental conditions: modulation amplitude, $5 \mathrm{G}$; modulation frequency, $100 \mathrm{kHz}$; microwave power, $5 \mathrm{~mW}$; temperature, $77 \mathrm{~K}$. Note: $\times$ refers to the amount of signal amplification for presentation purposes.

added copper and the spectra have values of $g_{\mid l}=2 \cdot 23$ and $A_{\| l}=185 \mathrm{G}$, indicating more nitrogen coordination.

Time-course experiments showed that all the $\mathrm{Cu}(\mathrm{II})$ added was reduced to $\mathrm{Cu}(\mathrm{I})$ in $<10 \mathrm{~min}$ (Fig. 4). The $\mathrm{Cu}(\mathrm{I})$ associated with $\mathrm{mb}$ was stable for hours in oxygenated solutions and required molar excess of $\mathrm{H}_{2} \mathrm{O}_{2}$ to oxidize the $\mathrm{Cu}(\mathrm{I})$ to $\mathrm{Cu}$ (II) (Fig. 4). The $\mathrm{Cu}(\mathrm{II})$ remained associated with $\mathrm{mb}$ and can be observed by UV-visible absorption spectroscopy (W. E. Antholine, D. W. Choi, Y. S. Young \& A. A. DiSpirito, unpublished results). Upon extended incubation with $\mathrm{H}_{2} \mathrm{O}_{2}$, an EPR signal for the cupric site was obtained with $\mathrm{g}_{11}=2 \cdot 23$ and $A_{11}=185 \mathrm{G}$, but without the resolved superhyperfine structure, possibly because there was more strain, multiple cupric sites or aggregation. In order to prevent free-radical reactions close to the cupric site, $\mathrm{HCO}_{3}^{-}$was added before $\mathrm{H}_{2} \mathrm{O}_{2}$ was added. Oxygen radicals react with $\mathrm{HCO}_{3}^{-}$to form $\mathrm{CO}_{2}$ and diffuse away from the cupric ion, preventing any reactivity with copper. The spectrum obtained after $30 \mathrm{~min}$ was better-defined in the $\mathrm{g}_{11}$ region with $\mathrm{g}_{11}=2 \cdot 20$ and $\mathrm{A}_{1 \mathrm{l}}=182 \mathrm{G}$, along with two or three nitrogen-donor atoms.

\section{$\mathrm{Cu}(\mathrm{II}), \mathrm{Cu}-\mathrm{mb}$ and substrate effects on the EPR spectra in membrane samples}

The stimulatory effect of $\mathrm{Cu}-\mathrm{mb}$ on propylene oxidation by the pMMO suggests a potential role of $\mathrm{Cu}-\mathrm{mb}$ in methane oxidation by the pMMO. To examine the possible cause for this stimulation, the EPR spectral properties in the washed membrane fraction were examined following the addition of $\mathrm{Cu}-\mathrm{mb}$ in the presence and absence of a reductant, $\mathrm{NADH}$, and substrates, $\mathrm{CH}_{4}$ and/or $\mathrm{O}_{2}$. To minimize

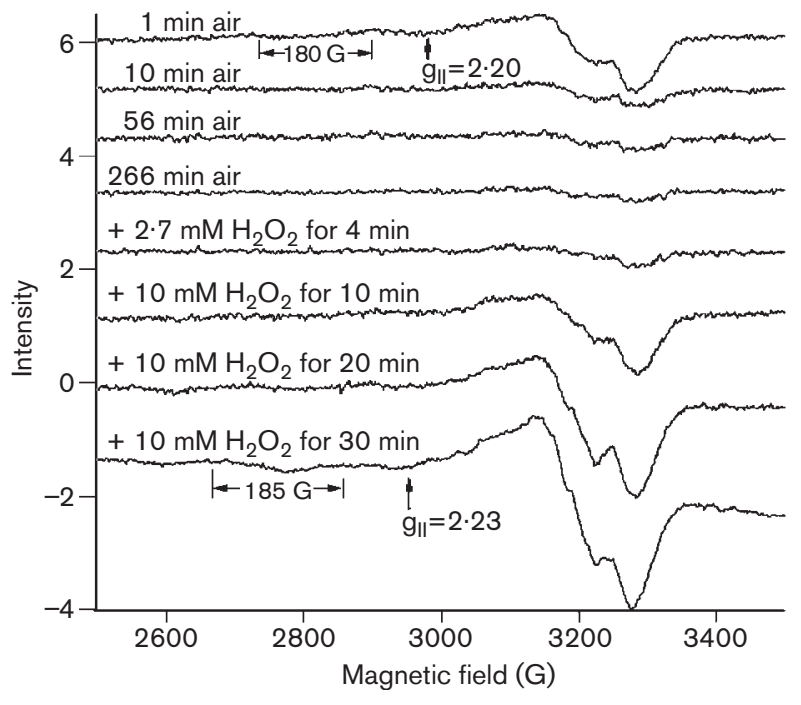

Fig. 4. X-band EPR spectra of $2 \cdot 7 \mathrm{mM} \mathrm{mb}$ following the addition of $0.7 \mathrm{mM} \mathrm{CuSO}$. Following copper addition, samples were incubated for $1,10,56$ and $266 \mathrm{~min}$ at room temperature, then frozen in liquid nitrogen. In samples $(2.7 \mathrm{mM} \mathrm{mb}$ plus $0.7 \mathrm{mM} \mathrm{CuSO}_{4}$ ) treated with $\mathrm{H}_{2} \mathrm{O}_{2}$, the $\mathrm{H}_{2} \mathrm{O}_{2}$ was added to a final concentration of $2 \cdot 7$ or $10 \mathrm{mM}$ and incubated for 4 , 10,20 or $30 \mathrm{~min}$ at room temperature, then frozen in liquid nitrogen. $A_{\|}$and $g_{\|}$are indicated by lines and arrows. Experimental conditions: modulation amplitude, $5 \mathrm{G}$; modulation frequency, $100 \mathrm{kHz}$; microwave power, $5 \mathrm{~mW}$; temperature, $77 \mathrm{~K}$.

variability in the spectral characterization of the pMMO, the membranes were isolated and reaction vials were prepared under anaerobic conditions. In reaction mixtures containing $\mathrm{O}_{2}$ and/or $\mathrm{CH}_{4}$, the gases were added with gastight syringes to closed $6 \mathrm{ml}$ serum vials in the anaerobic chamber. Under these conditions, the EPR-detectable $\mathrm{Cu}(\mathrm{II})$ in the pMMO was reduced by $50-65 \%$ and the addition of $\mathrm{NADH}$ did not result in additional reduction of the type II $\mathrm{Cu}(\mathrm{II})$ centres associated with the pMMO [Fig. 5a, traces (i) and (ii)]. The inability to reduce the remaining copper centres may represent the physiological resting state of the enzyme or it may represent the population of inactive enzyme in these preparations. Addition of $\mathrm{CH}_{4}$ did not change the spectral properties [Fig. $5 \mathrm{a}$, trace (iii)]. However, in the presence of $\mathrm{O}_{2}$, the intensity of the type II Cu(II) signal was increased by approximately $50 \%$ and a free-radical signal was generated at $g=2.005$ [Fig. 5a, trace (iv)]. The addition of methane and oxygen resulted in spectra that were similar to the spectra of $\mathrm{O}_{2}$ alone, but the free-radical signal was reduced by $40 \%$ [Fig. 5a, trace (v)]. These results suggest that, as in the sMMO (Wallar \& Lipscomb, 1996, 2001), the pMMO activates oxygen before reacting with methane.

Depending on the sample preparation, two different EPR spectral changes were observed following the addition of $\mathrm{Cu}-\mathrm{mb}$ and NADH. Fig. 5(b) illustrates one of the EPR 

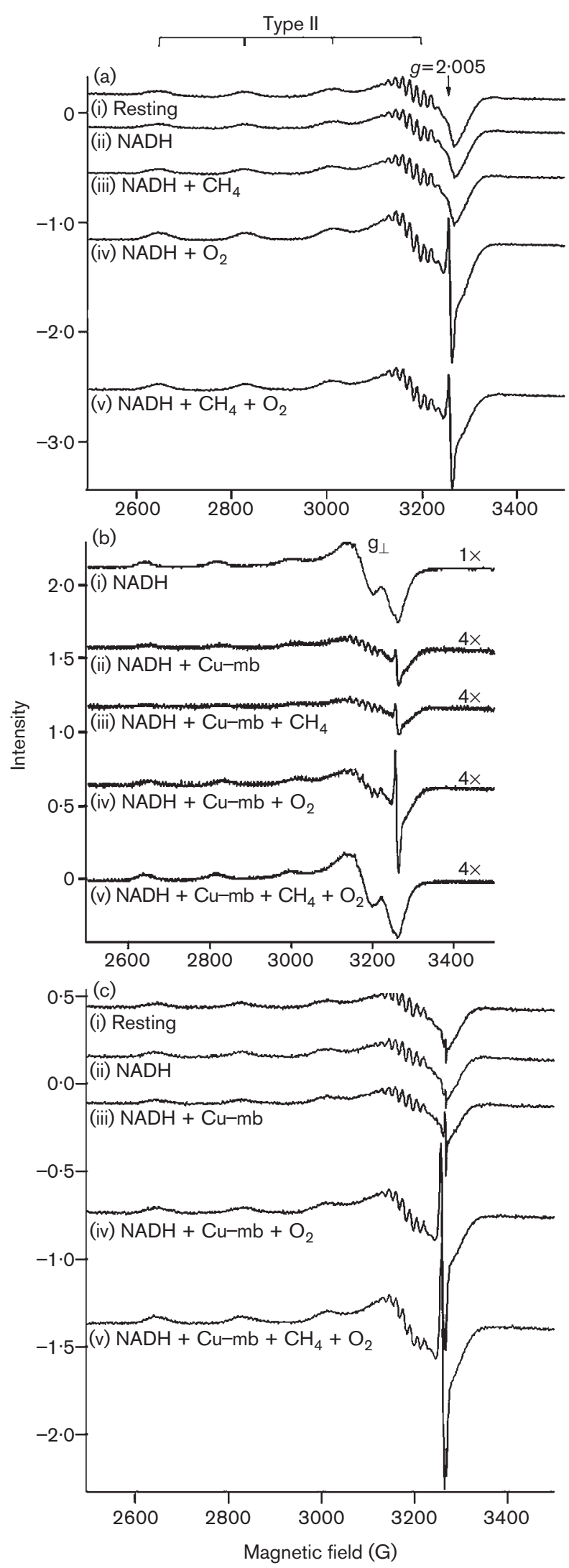

spectral changes observed in the high-activity membrane preparations. In the presence of a reductant, the addition of
Fig. 5. Effect of $\mathrm{Cu}(\mathrm{II}), \mathrm{Cu}-\mathrm{mb}, \mathrm{NADH}, \mathrm{O}_{2}$ and $\mathrm{CH}_{4}$ addition on $\mathrm{X}$-band EPR spectra at $77 \mathrm{~K}$ of the cupric site of the washed membrane fraction from Methylococcus capsulatus Bath expressing the pMMO isolated under anaerobic conditions. (a) and (b) were from the washed membrane samples used in Fig. 1(b) and samples used in (c) were from washed membrane samples shown in Fig. 1(c). In (a), the gain increased by a factor of $5.76 \mathrm{com}-$ pared with (b). (a) Effect of substrate additions on EPR spectra of the cupric site of the washed membrane fraction from Methylococcus capsulatus Bath: (i) resting; (ii) following the addition of $2.12 \mathrm{nmol} \mathrm{NADH}$ (mg membrane protein) ${ }^{-1}$; (iii) following the addition of $2.12 \mathrm{nmol} \mathrm{NADH}$ and $1.9 \mu \mathrm{mol} \mathrm{CH}_{4}$ (mg membrane protein) ${ }^{-1}$; (iv) following the addition of $2.12 \mathrm{nmol}$ NADH and $1.9 \mu \mathrm{mol} \mathrm{O}_{2}$ (mg membrane protein) ${ }^{-1}$; (v) following the addition of $2.12 \mathrm{nmol} \mathrm{NADH}, 1.9 \mu \mathrm{mol} \mathrm{CH}_{4}$ and $1.9 \mu \mathrm{M} \mathrm{O}_{2}$ (mg membrane protein $)^{-1}$. (b) Effect of $\mathrm{Cu}-\mathrm{mb}$ and substrate additions on EPR spectra of the cupric site of the washed membrane fraction from Methylococcus capsulatus Bath: (i) following the addition of $2.12 \mathrm{nmol} \mathrm{NADH}$; (ii) following the addition of $23.5 \mathrm{nmol} \mathrm{Cu}-\mathrm{mb}$ and $2.12 \mathrm{nmol} \mathrm{NADH}$ (mg membrane protein) ${ }^{-1}$; (iii) following the addition of $23.5 \mathrm{nmol} \mathrm{Cu}-\mathrm{mb}, 2.12 \mathrm{nmol} \mathrm{NADH}$ and $1.9 \mu \mathrm{mol}$ $\mathrm{CH}_{4}$ (mg membrane protein) ${ }^{-1}$; (iv) following the addition of $23.5 \mathrm{nmol} \mathrm{Cu}-\mathrm{mb}, 2.12 \mathrm{nmol} \mathrm{NADH}$ and $1.9 \mu \mathrm{mol} \mathrm{O}_{2}$; (v) following the addition of $23.5 \mathrm{nmol} \mathrm{Cu}-\mathrm{mb}, 2.12 \mathrm{nmol} \mathrm{NADH}$, $1.9 \mu \mathrm{mol} \mathrm{CH}_{4}$ and $1.9 \mu \mathrm{M} \mathrm{O}_{2}$ (mg membrane protein) $)^{-1}$. (c) Effect of $20 \mathrm{nmol} \mathrm{Cu}-\mathrm{mb}$ ( $\mathrm{mg}$ membrane protein) ${ }^{-1}$ on the loweractivity membrane fractions shown in Fig. 1(c): (i) resting; (ii) following the addition of $2.12 \mathrm{nmol} \mathrm{NADH}$ ( $\mathrm{mg}$ membrane protein) $)^{-1}$; (iii) following the addition of $20 \mathrm{nmol} \mathrm{Cu}-\mathrm{mb}$ and $2.12 \mathrm{nmol} \mathrm{NADH}$ ( $\mathrm{mg}$ membrane protein) ${ }^{-1}$; (iv) following the addition of $20 \mathrm{nmol} \mathrm{Cu}-\mathrm{mb}, 2.12 \mathrm{nmol} \mathrm{NADH}$ and $1.9 \mu \mathrm{mol} \mathrm{O}_{2}$ ( $\mathrm{mg}$ membrane protein) ${ }^{-1}$; (v) following the addition of $20 \mathrm{nmol}$ $\mathrm{Cu}-\mathrm{mb}, 2.12 \mathrm{nmol} \mathrm{NADH}, 1.9 \mu \mathrm{mol} \mathrm{CH}_{4}$ and $1.9 \mu \mathrm{M} \mathrm{O}_{2}$ (mg membrane protein $)^{-1}$. Instrument conditions were: modulation frequency, $100 \mathrm{kHz}$; modulation amplitude, $5 \mathrm{G}$; time constant, $100 \mathrm{~ms}$; microwave frequency, $9.191 \mathrm{GHz}$; microwave power, $5.0 \mathrm{~mW}$. Note: $\times$ refers to the amount of signal amplification for presentation purposes.

$\mathrm{Cu}-\mathrm{mb}$ resulted in the near-complete reduction of the type II $\mathrm{Cu}$ (II) signal associated with $\mathrm{pMMO}$ and the appearance of the free-radical signal at $g=2 \cdot 005$ [Fig. 5b, trace (ii)]. The near-complete reduction of the type II $\mathrm{Cu}$ (II) signal suggests that the majority of the pMMO in the washed membrane sample was active. The addition of $\mathrm{CH}_{4}$ did not alter the EPR spectral properties of the membrane in the presence of $\mathrm{Cu}-$ $\mathrm{mb}$ [Fig. 5b, trace (iii)]. However, the addition of $\mathrm{O}_{2}$ resulted in the reoxidation of the type II $\mathrm{Cu}$ (II) centre(s) of the pMMO and increased the intensity of the free-radical signal at $g=2 \cdot 005$ [Fig. 5b, trace (iv)]. Surprisingly, the addition of both $\mathrm{O}_{2}$ and $\mathrm{CH}_{4}$ to the membrane fraction in the presence of $\mathrm{Cu}-\mathrm{mb}$ resulted in the partial oxidation of the type II $\mathrm{Cu}$ (II) centre(s) without the formation of the radical signal at $g=2 \cdot 005$ [Fig. 5b, trace (v)].

In other membrane preparations, the reduction of the pMMO following addition of $\mathrm{Cu}-\mathrm{mb}$ was comparatively small (Fig. 5c). Also, as in the previous example (Fig. 5b), the addition of high concentrations of $\mathrm{Cu}-\mathrm{mb}$ 
did not increase the intensity of the $\mathrm{Cu}(\mathrm{II})$ signal in the washed membrane sample, suggesting that the copper associated with $\mathrm{mb}$ remained as $\mathrm{Cu}(\mathrm{I})$. In these membrane preparations, the intensity of the radical signal became larger following $\mathrm{O}_{2}$ addition [Fig. 5c, trace (iv)]. However, in contrast to the membrane series represented in Fig. 5(b), the addition of $\mathrm{CH}_{4}$ with $\mathrm{O}_{2}$ only resulted in partial quenching of the radical signal [Fig. 5c, trace (v)]. As a general rule, $\mathrm{Cu}(\mathrm{II})$ is known to stimulate pMMO activity in whole-cell as well as in cell-free fractions (Basu et al., 2003; Chan et al., 2004; Choi et al., 2003; Collins et al., 1991; Dalton et al., 1984; Lieberman et al., 2003; Nguyen et al., 1998; Zahn \& DiSpirito, 1996). However, in contrast to the copper added as $\mathrm{Cu}-\mathrm{mb}$, much of the added $\mathrm{Cu}$ (II) appeared as unassociated copper, which becomes more evident following the addition of $\mathrm{O}_{2}$ or $\mathrm{O}_{2}$ plus $\mathrm{CH}_{4}$ (results not shown).

\section{Effects of $\mathrm{mb}$ on the cupric signal in the $\mathrm{g}_{\perp}$ region}

One surprising result in the examination of membrane samples was the absence of the normally well-resolved superhyperfine structure in the $g_{\perp}$ region associated with the type II Cu(II) of the pMMO (Nguyen et al., 1996; Yuan et al., 1997, 1998a, b, 1999) [Fig. 5b, traces (i) and (v)]. This phenomenon was only observed in membrane preparations from cells cultured in high-copper, i.e. $80 \mu \mathrm{M} \mathrm{CuSO}_{4}$, medium, which has been shown to copper-saturate Methylococcus capsulatus Bath (Choi et al., 2003; Zahn \& DiSpirito, 1996). To examine whether $\mathrm{Cu}-\mathrm{mb}$ was responsible for the loss of superhyperfine structure associated with the pMMO, the effect of $\mathrm{mb}$ at different copper-to-mb ratios on the EPR spectra from washed membrane samples was examined. Fig. 6(a) shows the EPR spectra of the washed membrane sample from cells cultured in $80 \mu \mathrm{M} \mathrm{CuSO}_{4}$ medium. In these membrane samples, the type II $\mathrm{Cu}$ (II) superhyperfine structure was initially well-resolved (Fig. 6a, no-addition trace). However, the addition of mb containing copper-to$\mathrm{mb}$ ratios above $0.25 \mathrm{Cu}$ per $\mathrm{mb}$ resulted in the loss of copper superhyperfine structure, as well as the free-radical signal, at $g=2 \cdot 005$. At copper-to-mb ratios above $0 \cdot 25 \mathrm{Cu}$ per $\mathrm{mb}$, signal intensity increased in the cupric spectral region and was similar to $\mathrm{Cu}$ (II)-titration experiments with purified mb. Fig. 6(b) shows the EPR spectra of washed membrane samples from cells cultured in $60 \mu \mathrm{M} \mathrm{CuSO}_{4}$, where maximal expression of the pMMO has been observed (Choi et al., 2003; Zahn \& DiSpirito, 1996). In these membrane samples, the addition of mb with higher $\mathrm{Cu}(\mathrm{II})$-to-mb ratios decreased, but did not eliminate, the resolution of the superhyperfine structure in the $g_{\perp}$ region. The results suggest that the loss of cupric superhyperfine structure in some membrane preparations was the result of the high $\mathrm{Cu}-\mathrm{mb}$ concentrations. We speculate that the decrease in the resolution of the superhyperfine structure resulted from reduction and/or presence of multiple signals in this region. Increased resolution of the superhyperfine signal following the removal of $\mathrm{Cu}-\mathrm{mb}$ has also been observed in purified pMMO preparations (Choi et al., 2003).

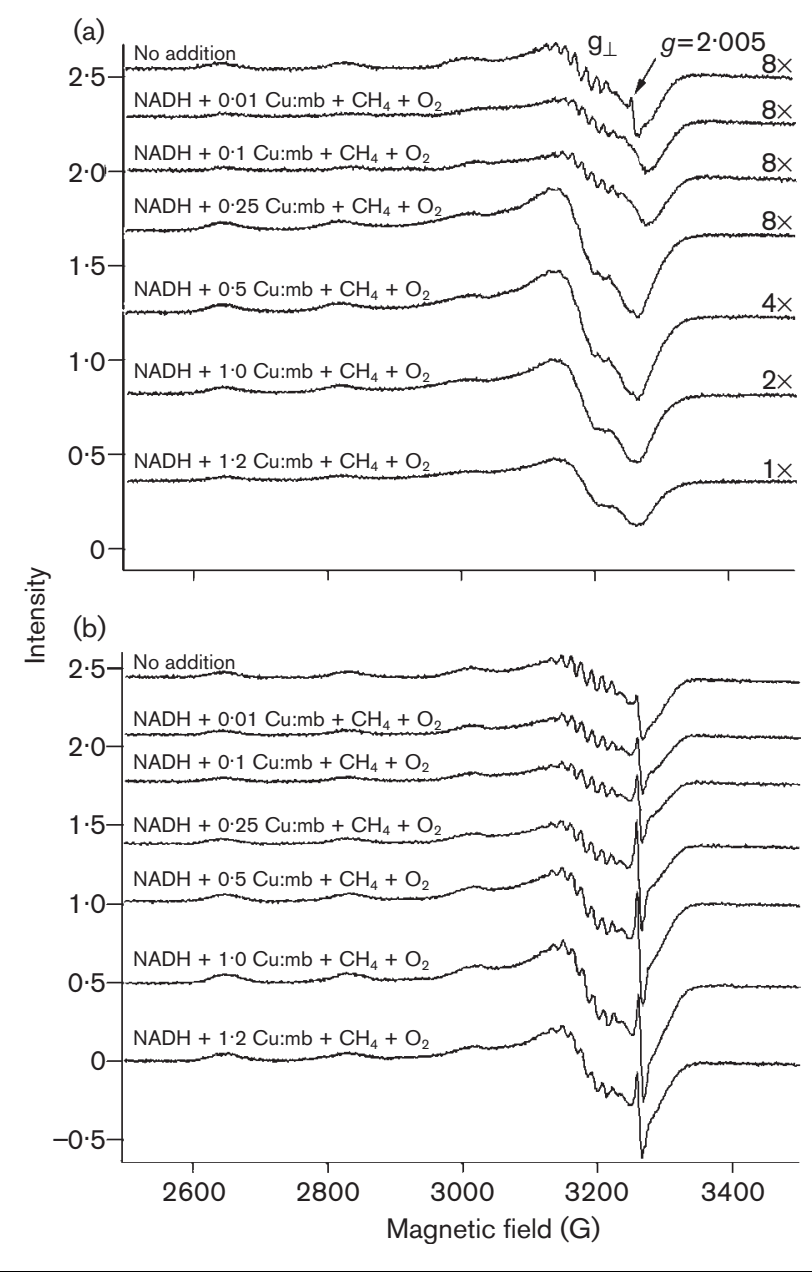

Fig. 6. X-band EPR spectra at $77 \mathrm{~K}$ of the cupric site of the washed membrane fraction from Methylococcus capsulatus Bath cultured in $80 \mu \mathrm{M}$ (a) and $60 \mu \mathrm{M}$ (b) $\mathrm{CuSO}_{4}$ media. Samples were first incubated with or without the addition of $\mathrm{mb}$ containing different copper-to-mb molar ratios, followed by the addition of $\mathrm{NADH}, \mathrm{O}_{2}$ and $\mathrm{CH}_{4}$. Instrument conditions were identical to those in Fig. 5. Note: $\times$ refers to the amount of signal amplification for presentation purposes.

\section{DISCUSSION}

Studies on the association of $\mathrm{mb}$ or $\mathrm{Cu}-\mathrm{mb}$ with the $\mathrm{pMMO}$ had been limited, as the only positive correlation between these two molecules was the irreversible loss of methaneoxidation activity following dissociation of these two molecules (Choi et al., 2003; Zahn \& DiSpirito, 1996). However, previous studies were performed by using purification procedures involving one or more steps at $\mathrm{pH}$ values of $4 \cdot 0$ or lower (Zahn \& DiSpirito, 1996), which is now known to destabilize the molecule (Kim et al., 2004). In addition, no precautions were taken for possible photodegradation. Furthermore, previous attempts at stimulation of pMMO activity in cell-free fractions added $\mathrm{mb}$ and $\mathrm{Cu}(\mathrm{II})$ separately for control purposes. In this study, $\mathrm{mb}$ samples were mixed with copper and incubated for a 
minimum of $5 \mathrm{~min}$ before addition to reaction mixtures containing pMMO. Initially, this difference would appear trivial, but considering the inhibitory effects of mb samples with copper-to-mb ratios below $0.6 \mathrm{Cu}$ per $\mathrm{mb}$, this difference in addition methodology becomes significant. Another difference between this and previous studies was the higher methane-oxidation activities in the washed membrane fractions. The methane-oxidation activity in the washed membrane samples from previous studies was $<20 \%$ of the methane-oxidation activity in the samples used in this report. Lastly, the inhibitory effects of $\mathrm{mb}$, with copper-to-mb molar ratios below $0.6 \mathrm{Cu}$ per mb, on methane oxidation by the pMMO also demonstrate the importance of $\mathrm{Cu}$ (II)-to-mb ratio in the final sample. The inhibition in samples with copper-to-mb ratios below $0 \cdot 6$ $\mathrm{Cu}$ per mb may be due to the removal of copper or other metal(s), such as Fe, from membrane samples.

The EPR and kinetic experiments described here suggest that $\mathrm{Cu}-\mathrm{mb}$ is a redox-active chromopeptide that stimulates methane oxidation by pMMO. This stimulation was equal to or greater than that observed with $\mathrm{Cu}(\mathrm{II})$ and without the toxicity observed at higher $\mathrm{Cu}(\mathrm{II})$ concentrations. The stimulation of pMMO activity was similar to the stimulation observed previously with $\mathrm{P}$-centre inhibitors of the $b c_{1}$ complex, such as mixothiazol and stigmatellin (Brand \& Trumpower, 1994; Choi et al., 2003; DiSpirito et al., 2004; Matsumo-Yagi \& Hatefi, 1999; Zahn \& DiSpirito, 1996; Zhang et al., 1998). Stimulation of pMMO activity by mixothiazol and stigmatellin has been interpreted as resulting from either the preferential shuttling of electrons to the pMMO or that the pMMO has a quinone- or semiquinonebinding site (DiSpirito et al., 2004). Most of the available evidence supports the second interpretation (Basu et al., 2003; Choi et al., 2003; DiSpirito et al., 2004; Shiemke et al., 1995, 2004; Zahn \& DiSpirito, 1996).

The EPR studies presented here suggest interactions between $\mathrm{Cu}-\mathrm{mb}$ and the type II $\mathrm{Cu}$ (II) centre of the $\mathrm{pMMO}$ and $\mathrm{Cu}-\mathrm{mb}$. The results also suggest that $\mathrm{Cu}-\mathrm{mb}$ is the probable source of the variability, complexity and controversy associated with the copper centres of the pMMO (Basu et al., 2003; Chan et al., 2004; Choi et al., 2003; Lieberman et al., 2003; Lieberman \& Rosenzweig, 2004, 2005; Nguyen et al., 1994, 1996, 1998; Takeguchi \& Okura, 2000; Takeguchi et al., 1999; Téllez et al., 1998; Yuan et al., 1997, 1998a, b, 1999; Zahn \& DiSpirito, 1996). Laboratories examining the pMMO have differed in the analysis of the EPR spectra. Results from studies using the washed membrane fraction from Methylomicrobium album BG8 (Yuan et al., 1997, 1998a, b, 1999) have suggested that the main, if not sole, source of the EPR spectrum is from a type II $\mathrm{Cu}(\mathrm{II})$ site. Other laboratories examining pMMO in Methylococcus capsulatus Bath have suggested that the spectrum associated with the PMMO is the sum of two EPR signals, one from a type II $\mathrm{Cu}(\mathrm{II})$ site and a second either associated with $\mathrm{Cu}-$ mb (Choi et al., 2003; Zahn \& DiSpirito, 1996) or from a trinuclear Cu(II) cluster (Chan et al., 2004; Nguyen et al.,
1994, 1996, 1998). mb from Methylomicrobium album BG8 has also been isolated recently (D. W. Choi, Y. S. Young \& A. A. DiSpirito, unpublished results). However, the concentrations of $\mathrm{Cu}-\mathrm{mb}$ in the washed membrane fractions from Methylomicrobium album BG8, cultured in NMS medium containing $5-10 \mu \mathrm{M} \mathrm{CuSO}_{4}$, were $<10 \%$ of the concentration observed in the membrane fractions from either Methylococcus capsulatus Bath or Methylosinus trichosporium $\mathrm{OB} 3 \mathrm{~b}^{\mathrm{T}}$. The lower concentration of $\mathrm{Cu}-\mathrm{mb}$ in Methylomicrobium album BG8 may account for the lesscomplex and better-resolved superhyperfine structure in the $\mathrm{g}_{\perp}$ region in samples, as previous studies have shown an increased resolution of superhyperfine structure in the $g_{\perp}$ region following separation of $\mathrm{Cu}-\mathrm{mb}$ from the $\alpha \beta \gamma$ subunits of the pMMO from this organism (Choi et al., 2003). Taken together, the results support the view that the site of the second EPR signal is from $\mathrm{Cu}-\mathrm{mb}$.

In conclusion, the results presented here provide the first direct evidence for the role of $\mathrm{Cu}-\mathrm{mb}$ in methane oxidation by the pMMO. The exact mechanism of stimulation is still unknown, but the results suggest that $\mathrm{Cu}-\mathrm{mb}$ increases electron flow to the type II $\mathrm{Cu}(\mathrm{II})$ centre(s) in the pMMO and may be involved in radical formation. $\mathrm{Cu}-\mathrm{mb}$ may also have a secondary role in protection against oxygen radicals and/or delivery of copper to the pMMO, as speculated earlier (Choi et al., 2003; DiSpirito et al., 2004).

\section{ACKNOWLEDGEMENTS}

This work was supported by the Department of Energy grant 0296ER20237 (to A. A. D. and W.E. A.).

\section{REFERENCES}

Basu, P., Katterle, B., Andersson, K. K. \& Dalton, H. (2003). The membrane-associated form of methane mono-oxygenase from Methylococcus capsulatus (Bath) is a copper/iron protein. Biochem J 369, 417-427.

Boas, J. F. (1984). Electron paramagnetic resonance of copper proteins. In Copper Proteins and Copper Enzymes, pp. 2-26. Edited by R. Lontie. Boca Raton, FL: CRC Press.

Brand, U. \& Trumpower, B. (1994). The protonmotive Q cycle in mitochondria and bacteria. Crit Rev Biochem Mol Biol 29, 165-197.

Brusseau, G. A., Tsien, H.-C., Hanson, R. S. \& Wackett, L. P. (1990). Optimization of trichloroethylene oxidation by methanotrophs and the use of a colorimetric assay to detect soluble methane monooxygenase activity. Biodegradation 1, 19-29.

Chan, S. I., Chen, K. H.-C., Yu, S. S.-F., Chen, C.-L. \& Kuo, S. S.-J. (2004). Toward delineating the structure and function of the particulate methane monooxygenase from methanotrophic bacteria. Biochemistry 43, 4421-4430.

Choi, D.-W., Kunz, R. C., Boyd, E. S. \& 7 other authors (2003). The membrane-associated methane monooxygenase (pMMO) and pMMO-NADH:quinone oxidoreductase complex from Methylococcus capsulatus Bath. J Bacteriol 185, 5755-5764.

Collins, L. M. P., Buchholz, L. A. \& Remsen, C. C. (1991). Effect of copper on Methylomonas album BG8. Appl Environ Microbiol 57, $1261-1264$. 
Dalton, H., Prior, S. D., Leak, D. J. \& Stanley, S. H. (1984). Regulation and control of methane monooxygenase. In Microbial Growth on $C_{1}$ Compounds, pp. 75-82. Edited by R. L. Crawford \& R. S. Hanson. Washington, DC: American Society for Microbiology.

DiSpirito, A. A., Zahn, J. A., Graham, D. W., Kim, H. J., Larive, C. K., Derrick, T. S., Cox, C. D. \& Taylor, A. (1998). Copper-binding compounds from Methylosinus trichosporium OB3b. J Bacteriol 180, 3606-3613.

DiSpirito, A. A., Kunz, R. C., Choi, D. W. \& Zahn, J. A. (2004). Electron flow during methane oxidation in methanotrophs. In Respiration in Archaea and Bacteria, pp. 141-169. Edited by D. Zannoni. The Netherlands: Kluwer Scientific.

Fitch, M. W., Graham, D. W., Arnold, R. G., Agarwal, S. K., Phelps, P., Speitel, G. E., Jr \& Georgiou, G. (1993). Phenotypic characterization of copper-resistant mutants of Methylosinus trichosporium OB3b. Appl Environ Microbiol 59, 2771-2776.

Henry, E. R. \& Hofrichter, J. (1992). Singular value decomposition: application to analysis of experimental data. Methods Enzymol 210, 129-192.

Kim, H. J., Graham, D. W., DiSpirito, A. A., Alterman, M. A., Galeva, N., Larive, C. K., Asunskis, D. \& Sherwood, P. M. A. (2004). Methanobactin, a copper-acquisition compound from methaneoxidizing bacteria. Science 305, 1612-1615.

Kim, H. J., Galeva, N., Larive, C. K., Alterman, M. \& Graham, D. W. (2005). Purification and physical-chemical properties of methanobactin: a chalkophore from Methylosinus trichosporium OB3b. Biochemistry 44, 5140-5148.

Lieberman, R. L. \& Rosenzweig, A. C. (2004). Biological methane oxidation: regulation, biochemistry, and active site structure of particulate methane monooxygenase. Crit Rev Biochem Mol Biol 39, 147-164.

Lieberman, R. L. \& Rosenzweig, A. C. (2005). Crystal structure of a membrane-bound metalloenzyme that catalyses the biological oxidation of methane. Nature 434, 177-182.

Lieberman, R. L., Shrestha, D. B., Doan, P. E., Hoffman, B. M., Stemmler, T. L. \& Rosenzweig, A. C. (2003). Purified particulate methane monooxygenase from Methylococcus capsulatus (Bath) is a dimer with both mononuclear copper and a copper-containing cluster. Proc Natl Acad Sci U S A 100, 3820-3825.

Matsumo-Yagi, A. \& Hatefi, Y. (1999). Ubiquinol:cytochrome $c$ oxidoreductase: effects of inhibitors on reverse electron transfer from the iron-sulfur protein to cytochrome b. J Biol Chem 274, 9283-9288.

Nguyen, H.-H. T., Shiemke, A. K., Jacobs, S. J., Hales, B. J., Lidstrom, M. E. \& Chan, S. I. (1994). The nature of the copper ions in the membranes containing the particulate methane monooxygenase from Methylococcus capsulatus (Bath). J Biol Chem 269, 14995-15005.

Nguyen, H.-H. T., Nakagawa, K. H., Hedman, B., Elliott, S. J., Lidstrom, M. E., Hodgson, K. O. \& Chan, S. I. (1996). X-ray absorption and EPR studies on the copper ions associated with the particulate methane monooxygenase from Methylococcus capsulatus (Bath). $\mathrm{Cu}(\mathrm{I})$ ions and their implications. J Am Chem Soc 118, 12766-12776.

Nguyen, H.-H. T., Elliott, S. J., Yip, J. H.-K. \& Chan, S. I. (1998). The particulate methane monooxygenase from Methylococcus capsulatus
(Bath) is a novel copper-containing three-subunit enzyme. J Biol Chem 273, 7957-7966.

Shiemke, A. K., Cook, S. A., Miley, T. \& Singleton, P. (1995) Detergent solubilization of membrane-bound methane monooxygenase requires plastoquinol analogs as electron donors. Arch Biochem Biophys 321, 421-428.

Shiemke, A. K., Arp, D. J. \& Sayavedra-Soto, L. A. (2004). Inhibition of membrane-bound methane monooxygenase and ammonia monooxygenase by diphenyliodonium: implications for electron transfer. J Bacteriol 186, 928-937.

Sommerhalter, M., Lieberman, R. L. \& Rosenzweig, A. C. (2005), $\mathrm{X}$-ray crystallography and biological metal centers: is seeing believing? Inorg Chem 44, 770-778.

Takeguchi, M. \& Okura, I. (2000). Role of iron and copper in particulate methane monooxygenase of Methylosinus trichosporium OB3b. Catal Surv Jpn 4, 51-63.

Takeguchi, M., Miyakawa, K. \& Okura, I. (1999). The role of copper in particulate methane monooxygenase from Methylosinus trichosporium OB3b. J Mol Catal 137, 161-168.

Téllez, C. M., Gaus, K. P., Graham, D. W., Arnold, R. G. \& Guzman, R. Z. (1998). Isolation of copper biochelates from Methylosinus trichosporium $\mathrm{OB} 3 \mathrm{~b}$ and soluble methane monooxygenase mutants. Appl Environ Microbiol 64, 1115-1122.

Wallar, B. J. \& Lipscomb, J. D. (1996). Dioxygen activation by enzymes containing binuclear non-heme iron clusters. Chem Rev 96, 2625-2658.

Wallar, B. J. \& Lipscomb, J. D. (2001). Methane monooxygenase component B mutants alter the kinetics of steps throughout the catalytic cycle. Biochemistry 40, 2220-2233.

Yu, S. S.-F., Chen, K. H.-C., Tseng, M. Y.-H., Wang, Y.-S., Tseng, C.-F., Chen, Y.-J., Huang, D.-S. \& Chan, S. I. (2003). Production of high-quality particulate methane monooxygenase in high yields from Methylococcus capsulatus (Bath) with a hollow-fiber membrane bioreactor. J Bacteriol 185, 5915-5924.

Yuan, H., Collins, M. L. P. \& Antholine, W. E. (1997). Low-frequency EPR of the copper in particulate methane monooxygenase from Methylomicrobium albus BG8. J Am Chem Soc 119, 5073-5074.

Yuan, H., Collins, M. L. P. \& Antholine, W. E. (1998a). Analysis of type $2 \mathrm{Cu}^{2+}$ in pMMO from Methylomicrobium album BG8. Biophys $J$ 74, A300.

Yuan, H., Collins, M. L. P. \& Antholine, W. E. (1998b). Concentration of $\mathrm{Cu}$, EPR-detectable $\mathrm{Cu}$, and formation of cupric-ferrocyanide in membranes with pMMO. J Inorg Biochem 72, 179-185.

Yuan, H., Collins, L. M. P. \& Antholine, W. E. (1999). Type $2 \mathrm{Cu}^{2+}$ in pMMO from Methylomicrobium album BG8. Biophys $J$ 76, 2223-2229.

Zahn, J. A. \& DiSpirito, A. A. (1996). Membrane-associated methane monooxygenase from Methylococcus capsulatus (Bath). J Bacteriol 178, 1018-1029.

Zhang, Z., Huang, L., Shulmeister, V. M., Chi, Y.-I., Kim, K. K., Hung, L.-W., Croft, A. C., Berry, E. A. \& Kim, S.-H. (1998). Electron transfer by domain movement in cytochrome $b c_{1}$. Nature 392, 677-684. 